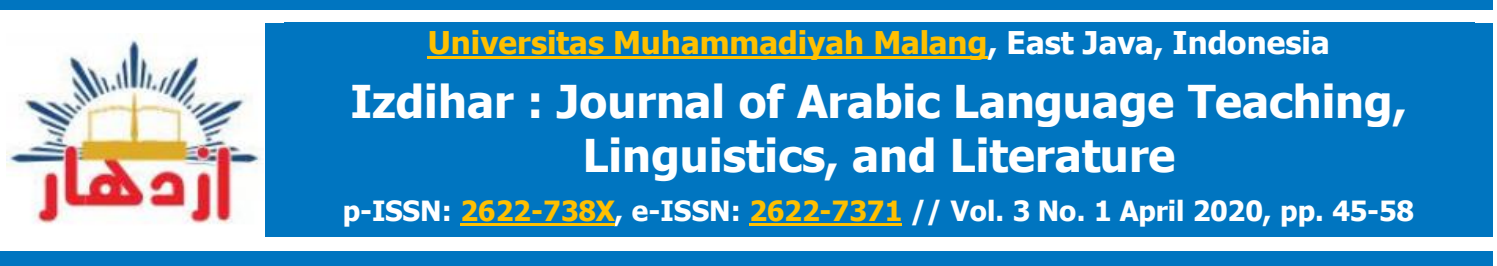

doi

\title{
Perspectives on the Arabic Language from University Student: Between Reality and Hope
}

\author{
Rijal Mahdia, 1 , Ahmad Asri Lubis ${ }^{b, 2}$ \\ aIAIN Syekh Nurjati Cirebon, Indonesia \\ bSultan Sharif Ali Islamic University, Brunei Darussalam \\ 11rijal_mahdi0123@syekhnurjati.ac.id*, 2asri.lubis@unissa.ed.bn
}

\section{ARTICLE INFO}

\section{Article History:}

Received: 01/04/2020

Revised: $27 / 04 / 2020$

Accepted: $29 / 04 / 2020$

Published: $30 / 04 / 2020$

\section{*Corresponding}

\section{Author:}

Name: Rijal Mahdi

Email:

rijal_mahdi0123@syekhnu rjati.ac.id

Keyword

\section{ABSTRACT}

Learning Arabic language has the ideal conditions that students want to achieve. therefore, the ideal condition is highly dependent on various factors. This research discusses the views or perspectives on the Arabic Language from students of IAIN Syekh Nurjati Cirebon that are enrolled in different faculties. This research contains several objectives: primarily to learn the direct thoughts of students on the Arabic language and its relevance within both national and international level. In addition, this study reveals the academic conditions of the students that has a direct correlation towards their preparedness and desire to receive studying materials in one semester whilst studying during first semester 2019 in from the total amount of sample that consists of 109 students. The researcher utilizes the survey method to perform the study along with empty cards as an aiding tool which was distributed among students. The empty papers that were provided were given to let students write their brief reasonings behind their perspective on Arabic Language. The outcome of this study shows that there were $40 \%$ of students having negative views towards the Arabic language, $45 \%$ of students with positive views while $10 \%$ of the research sample combines themes or contents closely related to the Arabic language. Furthermore, 5\% of student gave suggestions and ideas for learning Arabic language. This research has contributed in several ways especially in understanding the student's perspectives and opinions on Arabic language and help the lecturers to identify suitable teaching methods to use during the learning and teaching process.

Copyright (c) 2020, Mahdi et al

This is an open access article under the CC-BY-SA license

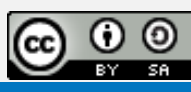

Cirebon; Ideal Conditions; Learning Objectives; Perspective

\begin{tabular}{|c|}
\hline مسيتخله البحث \\
\hline 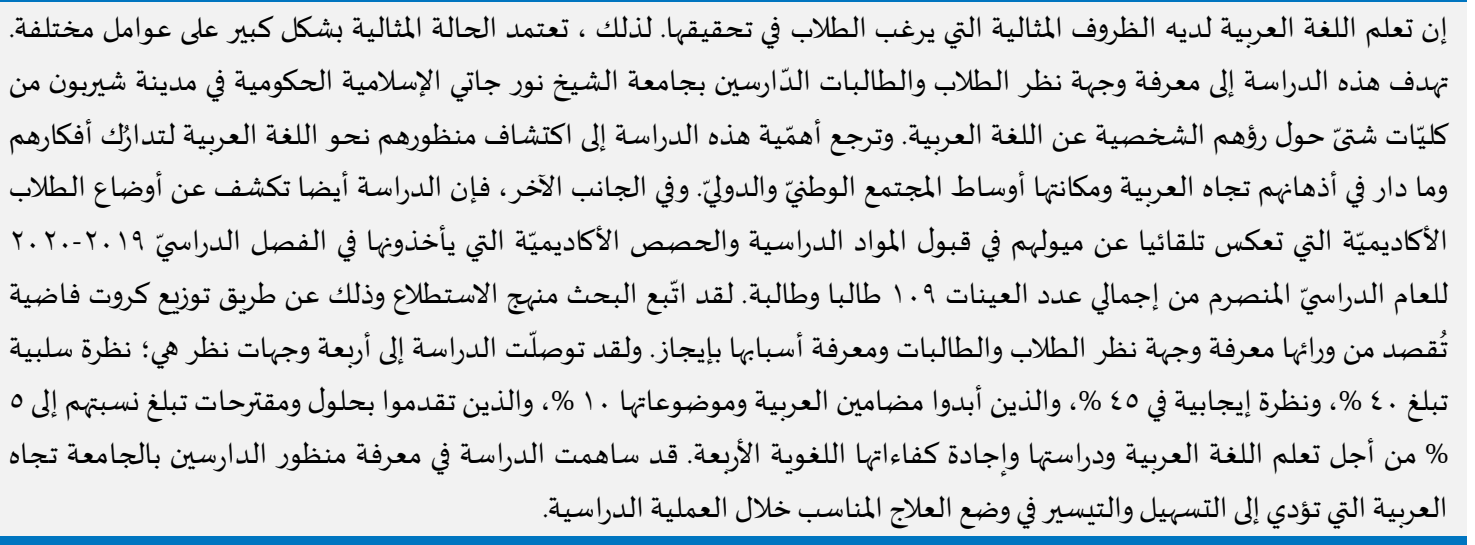 \\
\hline
\end{tabular}

Please cite this article as Mahdi, R., Lubis, A. A. (2020). Perspectives on the Arabic Language from

University Student: Between Reality and Hope. Izdihar : Journal of Arabic Language Teaching, Linguistics, and Literature, 3(1), 45-58. DOI: https://doi.org/10.22219/jiz.v3i1.11757 


\section{INTRODUCTION}

At the beginning of the new academic year 2019-2020 at IAIN Syekh Nurjati in Cirebon, West Java, the researcher was assigned to teach some Arab subjects in three main faculties of the university. The faculties are Faculty Tarbiyah and Teacher Training, Faculty of Sharia and Islamic Economics, and Faculty Ushuluddin, Adab, and Da'wah to undertake various academic subjects, including spelling and writing rules, introductory reading skill, supplementary reading skill, and book reading.

Classrooms consist of a large number of male and female students from various levels of education, as well as from various majors. This is the reason researchers ask questions at the beginning of learning activities for students to find out their perspectives about Arabic language learning that they learn for a semester and explore feeling and opinion in the minds of students. This question was also to know students' perspectives about Arabic language learning that they learned when they first went to school to determine learning approach that could be used like communicative language expansion approach, integrative approach (Chik, 2015), or other suitable approach such as relying on potential learners and their basic linguistics are known as "instinct theories" (Khasanah, 2018). It aimed to advance the role of students from recipients to active roles (Aqal, Sholeh, \& Shiyam, 2020) which focus on seeing students with all personal dimensions and human according to the theory of multiple intelligences (Alsweerky, 2020). Multiple intelligences as existential intelligence that exists among the nine types of intelligence that a person has (Hasanudin \& Fitrianingsih, 2020). In addition, many methodologies were used in teaching and learning such as silent method, collective language learning, suggestive methods, and complete physical response methods (As-Syuwairikh, 2016). The methods require great effort from students with all their emotional feelings and sensations (Fahrurrozi, 2014) to accept learning materials as a refresher to their innate impulse (Rusady, 2018) moreover considering their motivators and inclinations (Murdiono, 2018) without ignoring a teacher's strong belief in carrying out the required tasks (Ngui \& Lay, 2020).

It should be noted in this case, researchers looked forward to previous studies related to this research, because researchers try to photograph the study process at IAIN Syekh Nurjati with their research and studies. The researchers reached results and recommendations in the study. Sumiarni (2016) conducted a research illustrated this phenomenon with the study on teaching Arabic language for novice students at the Center for Language Development at IAIN Syekh Nurjati Cirebon (Problems and Solutions)". Some points that differ from previous study are this research focuses on solutions and 
suitable learning methods that was implemented by researchers for one semester based on preliminary information from previous studies.

The abovementioned phenomenon emphasizes the importance of this study, because the situation and conditions were intended by the need to accept students who have not yet learned Arabic and who have no experience in friction and dealing with Arabic as well as it occurs in other Islamic government universities, not only in IAIN Syekh Nurjati Cirebon only. The same problem also occurs at IAIN Tulungagung (Nurcholis \& Hidayatullah, 2019). They conducted research on the challenge of postgraduate students at a university to learn Arabic at IAIN Tulungagung in the fourth industrial era. This study discussed some problems that occured in teaching Arabic, including weak intention and motivation to learn Arabic, lack of self-awareness to create a suitable environment for learning Arabic, starting with a variety of student input, recognition from lecturers who are unable to speak the language Arabic and other problems. Although this research toke place in one place, this research focused on students' perspectives on Arabic in general and deals with samples from various universities and different educational institutions.

Gazali (2019) conducted research on the challenges and abilities possessed by the Arabic Department at the university in the fourth industrial era between challenge and ability. It discussed the raw materials possessed by the Arabic Department at IAIN Syekh Nurjati that was utilized to build a generation suitable for the modern era by using modern technology and taking educational methods to reach fruitful linguistic cadres qualified in the fields of Arabic language and literature.

This research is different from what previous research handled. It only dealt with one part of various university departments, but this research will deal with subjects in a wider range because the sample used came from three different tertiary faculties in universities, although there is a point of convergence between the two studies, namely the formation of competent generations in Arabic Language and Literature.

Ummi and Mulyaningsih (2016) conducted a study on the application of constructive theory in Arabic learning at IAIN Syekh Nurjati which focuses on student freedom in learning activities. This study also helped students to achieve the individual competencies they have in various ways. It also helped students' by expressing suggestions in their language and talking about their experiences related to learning to form an environment that is suitable for the process of receiving and conveying from an angle and enjoying the academic atmosphere in learning Arabic Language.

The focus that distinguishes this research from previous research is not only returning to students, but also for researchers in providing the best 
teaching materials for one semester. In addition, the sample used in this study is twice as many to provide useful results at the required level (Ummi \& Mulyaningsih, 2016).

Sumiarni and Syafrawi (2019) presented a study on the effectiveness of learning listening and speaking skills at a basic level in accordance with the Indonesian national qualification framework for students in Arabic education majors at IAIN Syekh Nurjati. This study aimed to measure students' level of understanding of listening skills material, in which students can understand Arabic speakers and understand Arabic texts in the manner needed based on the study plan in accordance with the national qualifications discussed at the academic workshop on October 29, 2016.

The different point in this research from previous research is in terms of the sample. The sample of previous research was based on one pattern and only in one part, the Arabic Language Education Department. As for this research, the sample included three colleges and three semesters, which seek comprehensive results towards a comprehensive vision and university, which can be measured at the university level as a whole.

The objectives of this study were partially met by developing a method to investigate students' general perspectives about Arabic language. Another objective is also to demonstrate the feasibility of students' hope and real condition on Arabic language learning in IAIN Syekh Nurjati. The key contribution of this work is the solution to provide suggestion for the appropriate methods and instructional matters based on students' psychological condition, educational background, and their perception toward Arabic learning.

\section{METHOD}

This research was qualitative research. Data was analyzed qualitatively. This study used a survey method to achieve general perspective by exploring the perspectives of male and female students in Arabic Language courses at three faculties in IAIN Syekh Nurjati. Researchers used white and blank cards that were distributed before starting learning activities at the first meeting of each course in one semester. The research samples are 109 students who study in three faculties. It should be noted, that the results of the study will be a basic reference for learning activities during one semester because it starts on an existing basis, where male and female students have understood the knowledge and information that has settled in their minds.

The survey in this study was important to do before starting the specific performance evaluation that must be completed and achieved because survey is a tool that aims to forecast general perspective trends by immediately 
identifying them with specific issues. A survey was also defined as an intention to seek opinions and not just wait for opinions to come, thus encouraging respondents to express opinions and problems they have not heard (Rumman, 2014). The trick was to find out the perspective of a person or group of a particular thing to find out their perceptions about things and encourage them to express their perspectives.

To find out students' perspectives, the researchers asked the question: What comes to mind when they hear the phrase "Arabic Language"? and the students need to explain the reason. Then the researchers distributed white blank cards to students as an exploration tool. It is to know the perspectives of 109 students consisting of third semester students from three classes in different faculties as explained in Tabel 1.

Tabel 1. Respondent of Research Samples

\begin{tabular}{ccc}
\hline No. & Faculty & Respondent \\
\hline $\mathbf{1}$ & Tarbiyah and Teacher Training & 39 \\
\hline $\mathbf{2}$ & Sharia and Islamic Economics & 35 \\
\hline $\mathbf{3}$ & Ushuluddin, Adab, and Da'wah & 35 \\
\hline & Total & 109
\end{tabular}

Tabel 1 explained about respondents or students that contained from three faculties. Respondents from Tarbiyah and Teacher Training Faculty were 39 students, 35 students were from Sharia and Islamic Economics Faculty, and 35 students were from Ushuluddin, Adab, and Da'wah Faculty. The research instruments also contained of question about the development of life from day to day, especially in the field of learning and education, which includes all developments in the elements of the teaching process, including teachers and students, learning materials, teaching methods, and instructional media.

Research data in the form of short essays were analyzed and presented in the form of narrative descriptive. For a short essay, the researchers tabulated the statements made by the students and then analyzed them based on the content of the statements. The tabulated data were categorized based on the frequency of statements so it produced a general description of students' perceptions toward Arabic learning. Interview data were also classified according to the general category of student perception.

\section{RESULTS \& DISCUSSION}

Please cite this article as Mahdi, R., Lubis, A. A. (2020). Perspectives on the Arabic Language from University Student: Between Reality and Hope. Izdihar : Journal of Arabic Language Teaching, Linguistics, and Literature, 3(1), 45-58. DOI: https://doi.org/10.22219/jiz.v3i1.11757 
Among the features of IAIN Syekh Nurjati, like other Islamic universities, is that Islamic subjects are taught there, including Arabic Language, because language in general is a product of the nation's civilization and a tool for transmitting historical and cultural heritage (Al-A 'araj \& Muqabalah, 2019), and language courses at universities.

\section{Students' General Perspectives about Arabic Language}

Language in general is a product of the nation's civilization and a tool for transmitting historical and cultural heritage (Al-A araj \& Muqabalah, 2019). Language courses at universities are basic courses that must be passed by students in accordance with a decision set by the Quality Assurance Department in one of the departments or one of the official centers established by the university in accordance with the organizational structure or mechanism of the university. Arabic Language learning at IAIN Syekh Nurjati is under the authority and responsibility of the center for language development at the university in accordance with the strategic plan of the university which assigns the Language Development Center to carry out the task.

\section{Tabel 2: Students' Perspectives about Arabic Language}

\begin{tabular}{clc}
\hline No. & \multicolumn{1}{c}{ Types of Perspectives } & Respondent \\
\hline 1. & Negative perspectives & 35 \\
\hline 2. & Positive perspectives & 45 \\
\hline 3. & $\begin{array}{l}\text { About contents and topics of Arabic } \\
\text { Language }\end{array}$ & 20 \\
\hline 4. & Learning solutions & 9 \\
\hline
\end{tabular}

Based on the sample represented in the data collection instrument in tabel 2, the researchers found the perspectives of students from three faculties at IAIN Syekh Nurjati. Students' perspectives about Arabic language were divided into four categories: (1) 35 students (32.11\%) have negative perspectives about Arabic Language; (2) 45 students (41.28\%) have positive perspectives about Arabic Language; (3) 20 students (18.35\%) did not express their perspectives on Arabic from both positive and negative sides but they mention the contents and topics; and (4) 9 students (8.26\%) provide solutions that can be used in Arabic Language learning and needed to master the four language skills. The results for this case was discussed briefly and clearly:

1. Students that have negative perspective considered that learning Arabic language is weird, difficult, uncomfortable to learn, eccentric, and confusing. Students that have positive perspective considered that learning 
Arabic is challenging, interesting, extraordinary, fun, happiness, enthusiasm, prestigious and special place, spacious, successful, creativity.

2. Students that have positive perspective considered that learning Arabic is Challenging, interesting, extraordinary, fun, happiness, enthusiasm, prestigious and special place, spacious, successful, creativity.

3. Other students talked about Arabic and its contents said that Arabic is language of The Holy Koran, the manuscripts. Most of them like Arabic history, Muhammad the Messenger of Allah that came from Arab, Arabic poetry and literature.

4. The last classification from students' perspective is solution in learning Arabic. Students must be enthusiastic, checking, and pheasant. In addition, language learners must practice more and more.

Islam (2015) said that there are many external factors that caused Arabic language learning demotivation, they are: 1) complexity of the Arabic language; 2) inadequate learning facilities and environment; and 3) monotonous learning methods and teaching materials. There are many internal factors that caused Arabic language learning demotivation, they are: 1) lack of basic skills and learning experience and 2) negative attitudes towards Arabic such as lack of interest and attention to learn Arabic.

In this case, the results of observations made by researchers indicated that external factors become the dominant factor that makes students have a negative perception toward Arabic learning. Though students must take Arabic courses as a prerequisite to take courses in the following semester. In addition, Arabic courses are a special feature of courses at IAIN Syekh Nurjati because many references for courses use Arabic language instruction.

Learning Arabic language is a process of teaching and learning activities carried out by Arabic teachers delivering knowledge to students (Fauzi, Buhun, \& Purwadi, 2019). In addition, students' interest and motivation become important points to reach learning outcomes and goals. Students, that have positive perception toward Arabic learning, have motives to master values not because of praise, values, and gifts but they are aware when doing learning activities without having to be told (Mukmin, 2019). They always realize the future advantage and benefit of lessons they learned. They are forward in learning in a certain period time and like to study.

The topics of Arabic learning should contain elements of knowledge about educational values. Behavioral educational values are necessary in the matter of education (Furqon \& Fauzi, 2019). Knowledge about educational values has many benefits. In addition to learning Arabic, students also learn about educational values that are important for them. 


\section{Students' Hope and Real Condition on Arabic Language Learning}

This research opened a broad field in determining the direction of the educational process towards learning Arabic as a foreign language. It is an important point in determining the output of students and graduates to achieve high competence and balanced quality that is in line with the opportunities available to Department of Arabic Language and Literature as a model as an important and integral part in improving educational performance and its results in Arabic Language learning at IAIN Syekh Nurjati, which seeks to improve the level of quality in accordance with the university's strategic plan for year 20202030.

Arabic language learning in Indonesia needs attention. Learning Arabic is started from elementary, secondary, and higher education. In higher education, the development of Arabic learning according to Wahab (2016) is aimed at four things: (1) religious orientation, namely learning Arabic for the purpose of understanding Islamic teachings; (2) academic orientation, namely learning Arabic for the purpose of understanding science knowledge and Arabic language skills (istimâ', kalâm/tahadduts, qirâ'ah, and kitâbah) plus translation; (3) professional/practical and pragmatic orientation, namely learning Arabic for professional, practical or pragmatic purposes and interests; and (4) ideological and economic orientation, namely learning Arabic to understand and use Arabic as a medium for orientalism, capitalism, imperialism, etc. From the four learning orientations, only two things become learning orientation on campus and higher education, namely religious orientation and academic orientation. For the third orientation, it is only applied to students Department in Arabic.

Religious and academic orientation have not achieved learning objectives as it happened in IAIN Syekh Nurjati. In the fact, non-Arabic Department students have less interest in studying although, it has become compulsories course. These problems can be caused by several things, including the lack of motivation in learning because there is a perspective if Arabic is difficult and lacks the creativity of a lecturer to be able to meet the learning objectives. So even though students have studied Arabic (for non-Arabic Department) for one year, they cannot master Arabic language according to the learning orientation.

Thu'aimah (2010) said that Arabic learning can reach the target if it fulfills four things, namely the linguistic foundation, educational foundation, psychological foundation, and social foundation. On a linguistic foundation, students must be introduced to aspects of language, philosophy, and characteristics of Arabic until students understand material course. However, only few teachers start Arabic language learning by introducing linguistic aspects. So, it causes a perspective that Arabic learning is difficult to 
understand. For educative foundation, teachers must have a mature learning design, starting from devices, media, materials, so that learning takes place in a fun and not boring way. However, the reality of learning Arabic in tertiary institutions seems to be boring, especially Arabic learning which a compulsory curriculum is for all non-Arabic language students. The problem is some of the instructors are not from the Arabic Language Educational Department so they lack understanding of pedagogical concepts.

Psychological foundation is also something that needs attention. Teachers should pay attention to the potential, abilities, needs, interests and talents, motivation, and individual differences of students. Based on researchers' observation in three other classes of Arabic course, psychological foundation does not become concern of some teachers in IAIN Syekh Nurjati, so that in the transfer of knowledge students are less able to receive maximal, and the learning objectives of Arabic learning is less achieved. The last foundation is socio-culture. It should also be concern to teachers. Students, who are not from Arabic Department in IAIN Syekh Nurjati, are sometimes receive less benefits, because the media and material are not integrated with their knowledge. To maximize this foundation, teachers must integrate material with students' knowledge and needs in the community.

Based on the previous explanation, it is very clear that the problem in the first group of students is an important point. This is the main reason behind that perspective, that students have just come to know Arabic as the foreign language they are learning so it requires a lot of effort, because learning a foreign language is a new thing to these students, so that first, learning a second language or a foreign language is not easy, and second, learning a second language is a complex process that includes an unlimited number of variables. While the second group of students is the opposite of the first group of students, they feel proud of Arabic because it is a religious language that occupies an important position in global communication and that is another advantage of Arabic among other languages in the world. The reason, according to the researchers' view, is that there was a prior relationship between students and Arabic language lessons at the level of education before students entered university or previous foreign language learning experiences (Barkat, 2017) during the lives of these students. As for the third group of students, they are those who mention Arabic topics or themes without expressing their personal perspectives of Arabic Language positively or negatively, while the last category, they make constructive suggestions in learning Arabic.

\section{CONCLUSIONS}

Please cite this article as Mahdi, R., Lubis, A. A. (2020). Perspectives on the Arabic Language from University Student: Between Reality and Hope. Izdihar : Journal of Arabic Language Teaching, Linguistics, and Literature, 3(1), 45-58. DOI: https://doi.org/10.22219/jiz.v3i1.11757 
The study was conducted on students in three faculties, namely Faculty Tarbiyah and Teacher Training; Faculty of Sharia and Islamic Economics; and Faculty Ushuluddin, Adab, and Da'wah at IAIN Syekh Nurjati in Cirebon, West Java, with a sample 109 students. There were four points of view that students have regarded Arabic language learning, which is negative perspective reached $32,11 \%$ of the total sample and positive perspective reached $41,28 \%$ of the total sample. While perspectives that stated about the contents and topics of Arabic amounted to $18,35 \%$ of the total number of samples and perspectives that provided suggestions and solutions for learning Arabic reached 8,26\% of the total number of samples. Arabic language becomes important and integral part in improving educational performance and its results in Arabic Language learning at IAIN Syekh Nurjati, which seeks to improve the level of quality in accordance with the university's strategic plan for year 2020-2030. In the fact, students face many challenges in Arabic complexity, inadequate learning facilities and environment, and monotonous learning methods and teaching materials. In addition, many students are novice in Arabic learning. They are lack of Arabic basic skill and learning experience, lack of interest and attention in Arabic learning.

\section{ACKNOWLEDGMENT}

Thanks to all of staffs of the Arabic Language and Literature department and all the lecturers of the Faculty of Fundamentals of Religion, Arts and Advocacy at IAIN Syekh Nurjati in Cirebon, West Java, where I became an academic and lecturer. Finally, I express my sincere thanks to all students who as responden ini this research. May God reward them all and give the best rewards.

\section{BIBLIOGRAPHY}

Al-A `araj, R. R., \& Muqabalah, N. M. (2019). Designing an Educational Unit Based on McGraw-Hill Program and Measuring its Effect on Female Sixth Grade Students' Reading Comprehension in Jordan. International Center for Research \& Studies, 276), 365-386. DOI: https://doi.org/ISSN 2410-3152

Alsweerky, M. A. H. (2020). Analysis of the content of Arabic language courses for the secondary stage; Scientific and administrative track in the Kingdom of Saudi Arabia in light of the theory of multiple intelligences. Journal of Educational and Psychological Sciences, 4(3), 21-39. DOI: https://doi.org/ISSN: 2522-3399 
Al-Syua 'ibi, M. al-S. Q., \& Al-Syahrani, S. bin A. (2014). Assessing Quality of Educational Services from Students' Perspectives at King Khalid University. Thamar University Journal for Studies and Researches: Refereed Scientific Journal Focuses on Human Knowledge and Applied Sciences, 19(1), 316346.

Aqal, M. S., Sholeh, N. F., \& Shiyam, S. A. (2020). The Effectiveness of STEAM in Developing The Arabic Language Skills of The Secondgrade Students. IUG Journal of Educational and Psychology Sciences, 28(1), 25-47. https://journals.iugaza.edu.ps/index.php/IUGJEPS/article/view/7470/2939

As-Syuwairikh, S. N. (2016). Qadhaya Asasiyah Fi Ta 'lim Al-Lughah AlAtssaniyah (1st ed.). Wojooh Publishing \& Distribution House. https://kaica.org.sa/links/epubs/ep004.pdf

Barkat, M. (2017). Limaza Yata 'llamu Al-Ba 'dh Al-Lughat Al-Ajnabiyah Bishuhulah ? https://www.alaraby.co.uk/jeel/journalism/2017/2/24/-lib يتعلم-البعض-اللغات-الأحنسة-سيسولة

Chik, A. R. Bin. (2015). Al-Al’aab Al-Lughawiyah Fii Ta`limil Al-Lughah AlArabiyah Fii Al-Madaris Al-Ibtidaiyah Fii Barnamaaj (J-QAF) Fii Malaysia: Dirasah Tahliliyah. Arabiyât: Jurnal Pendidikan Bahasa Arab Dan Kebahasaaraban, 2(2), 278-298. DOI: https://doi.org/10.15408/a.v2i2.2089

Setyawan, E. (2016). Profil Unit Pelaksana Teknis (UPT) Pusat Pengembangan Bahasa (PPB) IAIN Syekh Nurjati Cirebon. IAIN SEJATI PRESS. http://web.Sheikhnurjati.ac.id/ppb/profil-upt-ppb/

Fahrurrozi, A. (2014). Pembelajaran Bahasa Arab: Problematika dan Solusinya. ARABIYAT: Jurnal Pendidikan Bahasa Arab Dan Kebahasaaraban, 1(2), 161-180. DOI: https://doi.org/10.15408/a.v1i2.1137

Fauzi, M. F., Buhun, M. F., \& Purwadi, A. (2019). The Influence of Teams Games Tournament (TGT) toward Students' Interest in Arabic Language Learning. Izdihar: Journal of Arabic Language Teaching, Linguistics, and Literature, 2(2), 135-148. DOI: https://doi.org/10.22219/jiz.v2i2.9986

Furqon, M. R., \& Fauzi, M. F. (2019). The Values of Educational Character in the Arabic Temples of Qasidah Burdah by Imam Bushiri. Izdihar: Journal of Arabic Language Teaching, Linguistics, and Literature, 2(1), 67-76. DOI: https://doi.org/10.22219/jiz.v2i1.8327

Ganeem, I. (2018). Hillul Musykilat: Istiratijiyatu Tadris Fa`alah Litathwiri Maharat Al-Luqhah Ladal Muta ' lallimin. El-Thumuhat, 1(2), 1-14. DOI: 


\section{https://doi.org/10.25299/elthumuhat.2018.vol1(2).2173}

Gazali, E. (2019). Menakar Tantangan dan Potensi Jurusan Bahasa dan Sastra Arab (BSA) IAIN Syekh Nurjati Cirebon di Era Pendidikan 4 . 0. Arabiyatuna: Jurnal Bahasa Arab, 3(2), 229-250. DOI:

https://doi.org/10.29240/jba.v3i2.857

Hasanudin, C., \& Fitrianingsih, A. (2020). Verbal Linguistic Intelligence of the First-Year Students of Indonesian Education Program: A Case in Reading Subject. European Journal of Educational Research, 9(1), 117-128. DOI: https://doi.org/10.12973/eu-jer.9.1.117

Islam, A. M. S. (2015). Faktor Demotivasi Pembelajaran Bahasa Arab dalam Perspektif Siswa Madrasah. Arabiyât: Jurnal Pendidikan Bahasa Arab dan Kebahasaaraban, 2(1), 1-16. DOI: https://doi.org/10.15408/a.v2i1.1511

Istiqomah, H., \& Mahliatussikah, H. (2019). Musykilat al-Tarbiyyah Tuwajihuha al-Thalabah fi Ta'allum al-Lughah al-Arabiyah li Ghairi al-Nathiqin Biha. Jurnal Al Bayan: Jurnal Jurusan Pendidikan Bahasa Arab, 11(2), 254-280. DOI: https://doi.org/10.24042/albayan.v\%vi\%i.5257

Kama, N. (2014). Language Learning Strategies and Teaching Arabic Styles for Non Arabic Speakers. September. https://doi.org/10.13140/2.1.2766.2725

Khasanah, N. (2018). Desain Pengembangan Kurikulum Pembelajaran Bahasa Arab Berbasis Pendekatan Potensi/Fitrah. Al-Mahara: Jurnal Pendidikan Bahasa Arab, 4(2), 159-180. DOI:

https://doi.org/10.14421/almahara.2018.042-01

Mei, S. Y., Ju, S. Y., \& Mohd, A. B. (2017). Cooperative Learning Strategy in Teaching Arabic for Non Native Speakers. European Journal of Social Sciences Education and Research, 11(2), 262-267. DOI:

https://doi.org/10.26417/ejser.v11i2.p261-266

Meredeen, S. (1993). Study For Servival and Succes For College Students (Mansyurat). London: Champan Publishing Ltd.

Mukmin, M. (2019). The Effect of Educational Background and Language Competence on Students' Arabic Language Motivation. Arabiyat: Jurnal Pendidikan Bahasa Arab dan Kebahasaaraban, 6(1), 36-52. DOI: https://doi.org/10.15408/a.v6i1.10484

Murdiono. (2018). Dirasah Halah an Muyuli Thalabah fi Ta`allum al-Lughah alArabiyah bil Madaris al-Mutawassithah al-Islamiyah bi Malang wa Batu. Izdihar: Journal of Arabic Language Teaching, Linguistic, and Literature, 
1(2), 153-166. DOI: https://doi.org/10.22219/izdihar.v1i2.7297

Musa, I. H. A., \& Aqal, M. S. (2019). The Effectiveness of Electronic Educational Environment Using Active Learning Strategies in Developing Future Thinking Skills in Technology among Female Seventh Graders. IUG Journal of Educational and Psychology Sciences, 276), 01-34. DOI: https://doi.org/ISSN 2410-3152

Ngui, G. K., \& Lay, Y. F. (2020). The Effect of Emotional Intelligence, SelfEfficacy, Subjective Well-Being and Resilience on Student Teachers' Perceived Practicum Stress: A Malaysian Case Study. European Journal of Educational Research, 9(1), 277-291. DOI: https://doi.org/10.12973/eujer.9.1.277

Nurcholis, A., \& Hidayatullah, S. I. (2019). Tantangan Bahasa Arab sebagai Alat Komunikasi di Era Revolusi Industri 4.0 pada Pascasarjana IAIN Tulungagung. Arabiyatuna: Jurnal Bahasa Arab, 3(2), 283-298. DOI: https://doi.org/10.29240/jba.v3i2.999

Rumman, T. A. (2014). Isthitla`Ar-Ra`i Al-A`am Fil Amal Khairi. International Center for Research \& Studies, 1(1), 154-183.

https://www.medadcenter.com/MedadMag/1/fahres

Rusady, A. T. (2018). Dawafi' al-Thullab fi Ta'allum al-Lughah al-'Arabiyyah wa Dawr al-Mu'allim fi Tarqiyatiha. Jurnal Izdihar: Journal of Arabic Language Teaching, Linguistics, and Literature, 1(1), 65-78. DOI:

https://doi.org/https://doi.org/10.22219/izdihar.v1i1.6563

Sumiarni, N. (2014). Pembelajaran Bahasa Arab Bagi Mahasiswa Pemula Di Pusat Bahasa dan Budaya (PBB) IAIN Syekh Nurjati Cirebon (Problematika dan Solusinya). Holistik: Journal for Islamic Social Sciences, 16(1), 19-38. DOI: https://doi.org/10.24235/holistik.v15i1.432

Sumiarni, N. (2016). Pembelajaran Bahasa Arab bagi Mahasiswa Pemula di Pusat Bahasa dan Budaya (PBB) IAIN Syekh Nurjati Cirebon (Problematika dan Solusinya). Holistik, 15(1),19-38. DOI:

https://doi.org/10.24235/holistik.v15i1.432

Sumiarni, N., \& Syafrawi, A. S. (2019). Efektifitas Pembelajaran Menyimak Dan Berbicara Untuk Pemula (Maharat Al-Istima' Wa Al-Kalam Lil Mustawa AlTamhidi) Berbasis KKNI Pada Mahasiswa Jurusan Pendidikan Bahasa Arab (PBA) IAIN Syekh Nurjati Cirebon. EL-IBTIKAR: Jurnal Pendidikan Bahasa Arab, 8(1), 78-92. DOI: https://doi.org/10.24235/ibtikar.v8i1.3910

Thu'aimah, R. A. (2010). Al-Marji' fi Manâhij Ta'limm al-Lughah al-'Arabiyyah li

Please cite this article as Mahdi, R., Lubis, A. A. (2020). Perspectives on the Arabic Language from University Student: Between Reality and Hope. Izdihar : Journal of Arabic Language Teaching, Linguistics, and Literature, 3(1), 45-58. DOI: https://doi.org/10.22219/jiz.v3i1.11757 
an-Nâthiqîn bi Lughât Ukhrâ. Cairo: Daar al-Fikr al-'Arabî.

Tosun, S. (2013). A Comparative Study on Evaluation of Turkish and English Foreign Language Textbooks. Procedia - Social and Behavioral Sciences, 70, 1374-1380. DOI: https://doi.org/10.1016/j.sbspro.2013.01.199

Ummi, H. U., \& Mulyaningsih, I. (2016). Penerapan Teori Konstruktivistik Pada Pembelajaran Bahasa Arab Di IAIN Syekh Nurjati Cirebon. Journal Indonesian Language Education and Literature, 1(2), 53-65. DOI: https://doi.org/10.24235/ileal.v1i2.600

Wahab, M. A. (2016). Standarisasi kurikulum pendidikan bahasa Arab di perguruan tinggi keagamaan Islam negeri. Arabiyat: jurnal pendidikan bahasa Arab dan kebahasaaraban, 3(1), 32-51. DOI: https://doi.org/10.15408/a.v3i1.3187

Wijaya, I. S., \& Pimada, L. H. (2019). Ta`lim al-Imla` bi Al-Wasit alMuta`addidah li Tarqiyah Maharah al-Kitabah fi al-Lughah al-`Arabiyyah. Jurnal Al Bayan: Jurnal Jurusan Pendidikan Bahasa Arab, 11(2), 320-339. DOI: https://doi.org/10.24042/albayan.v11i2.5266 